\title{
Framework for the Packaging Supply Chain of an Automotive Engine Company
}

\author{
K. Vöröskői ${ }^{1}$, P. Böröcz ${ }^{1}$ \\ ${ }^{1}$ Széchenyi István University, Department of Logistics and Forwarding \\ Egyetem tér 1., 9026 Győr, Hungary \\ Phone: +36 96503400 \\ E-mail: boroczp@sze.hu
}

\begin{abstract}
Automotive industrial groups consider the impacts of packaging very important, mainly focusing on the cost effectiveness and environmentally conscious nature thereof. In the literature, the packaging supply chain is not a significantly researched area as regards the supply of the complete automotive engines. But the selection of packaging and the relevant development process in engine production are among the main elements of the extensive automotive industry, because participants sometimes have the same interests and considerations. This way, decision-making and strategies on using different packaging solutions and systems can be very varied. The reason is that each automotive group practically produces its own engines and transports them to their assembling subsidiaries all over the world. These groups often apply similar logistics policies and supply systems to use, take-back and recover their packaging. This is being driven as much by group strategies as it is by the need to reduce costs and increase efficiency in supply chains. The focus of this paper will be on the components and elements of packaging supply chain management in the field of engine supply for automotive industry groups, and on how the decision-making framework is determined. This paper shows models defining the network process for decision-making within the automotive groups as regards the packaging supply chain.
\end{abstract}

Keywords: automotive, packaging, supply chain management, packaging supply chain (PSC)

\section{Introduction}

Cost effectiveness has always been a significant issue in corporate practice during the last decades, but it is also becoming more important in the field of packaging due to the intensive competition of the supply chains. In the field of packaging the decision of the companies aims to find and determine the optimal and ideal packaging functions and expenses. This decision basically concerns the mechanism of choosing between packaging systems, such as one-way (disposable) or reusable (returnable) ones [1].

One-way packaging is only suitable for one use. Reusable containers are loaded with products and shipped to the destination, then the empty container is sent back to the supplier, refilled with products and this cycle is repeated over and over again. In some cases it is an open-loop system, or in many cases reusable packaging is collected at a 
centralised return handling centre, where it is cleaned, stocked, and distributed for refilling [2]. The main problem with one-way packaging is the waste created after the usage, while relative production costs are lower. On the other hand, transportation and maintaining costs are a relevant issue in the case of returnable packaging [1][3].

Naturally, the environmental aspects are also becoming a part of these important processes, including the reduction of waste during production [4]. Furthermore, improving the efficiency of packaging is an important strategic goal for the organisations considering the aspects of sustainability and economy [5]. Legislation has also forced companies to rethink their packaging operations [6]. This is the reason for returnable packaging systems being used by many actors of automotive supply chains (ASC). Returnable packaging materials can be classified as a Returnable Transport Item (RTI) and they are usually part of a closed-loop supply chain (CLSC) [7][8].

This paper focuses on the characteristics of the ASC, the traditional packaging supply chain and the packaging supply chain of an engine company. The cost structure of returnable packaging - as one of the main aspects of selecting the right automotive packaging - is also discussed and divided into categories.

\section{Automotive market and the automotive supply chain (ASC)}

The automotive industry includes a wide range of companies and organizations involving the activities of design, development, manufacturing, marketing, and the sale of vehicles. This part of the industry is one of the world's most significant economic sectors by its revenue. However, the automotive market is very concentrated, namely the 10 largest automotive groups share almost $80 \%$ of the market [8].

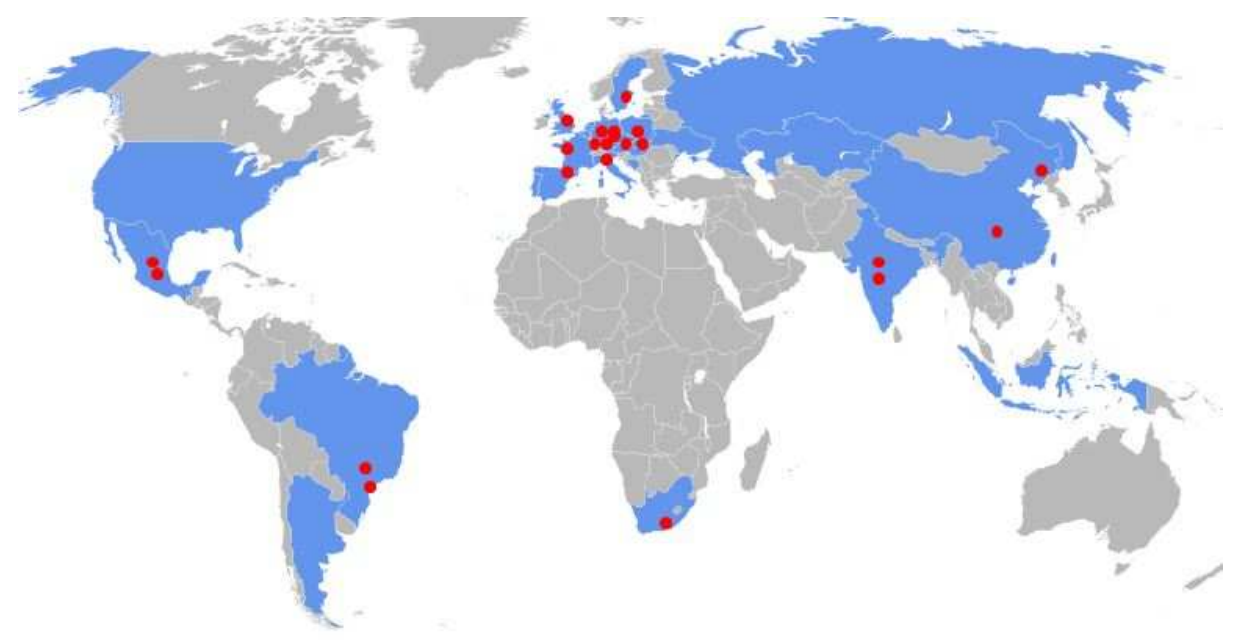

Figure 1. VW engine production facilities all over the world (based on [10])

For example, the German Volkswagen (VW) Group is one of the largest automakers in the world in 2016. As of May 2015, the Group operated 119 production plants only in 20 European countries and 11 additional facilities in countries in America, Asia and Africa. 
The Group produces nearly 41,000 vehicles every weekday. The VW Group sells its vehicles in 153 countries. Engine production is currently carried out at 24 plants all over the world [10], showed in Figure 1, which means cc. $20 \%$ of the total. At this point the authors wish to emphasise that this ratio shall be considered with considerable doubt, because only the VW Group was examined, so this ratio is not generally applicable to the entire automotive assembly industry.

Nowadays, an average car consists of more than 10,000 parts assembled by the Original Equipment Manufacturer (OEM), contributing to uncertainty regarding the necessary parts needed, and reducing the planning cycle in the logistical flow. Furthermore, a huge amount of parts arrives to the production facilities each day [11]. It is presumed that the complexity of these supply chains might increase even more in the future, despite the efforts that seek to simplify these processes. Several studies and forecasts have the same conclusion: the automotive market will grow continuously in the next 10 years [12][13].

The Automotive Supply Chain (ASC) is a global production and distribution network that starts with the mining of raw materials. The processed raw material is needed by the suppliers. The suppliers can manufacture single parts, more complex components or entire modules. As the last step of the chain, the OEM assembles all the parts into the final vehicle [14].

The role of OEM in the ASC is to acquire the components and to integrate them into the ready-made new vehicle. Therefore the major OEMs are mainly focus on core competencies. This means that the OEMs have shifted their focus from handling a large number of parts toward the assembly of entire modules, which are delivered directly from a significantly smaller number of suppliers than before [15]. Furthermore the suppliers could be divided into the categories of primary (first-tier), secondary (second-tier) and tertiary (third-tier to $n$-tier) subcontractors by the OEMs [16].

Based on the trend of focusing on core competencies, suppliers have an increasingly important function in the ASC. We shall also mention that the four main roles of suppliers have been classified by Veloso, Henry, Roth, and Clark (2000) as follows: systems integrator, global standardiser/systems manufacturer, component specialist or raw material supplier [17]. The details of these categories:

a) The systems integrator supplier has the ability to design and integrate components, subassemblies and systems into modules that are shipped directly by the supplier to the OEM's assembly plants. These modules can (for example) be the chassis, doors or the interiors.

b) Global standardiser/systems manufacturers are companies which set the global standard for a component or system. They design, develop and manufacture these systems and supply the OEMs directly or indirectly via the systems integrator [17].

c) The component specialist carries out the design and manufacturing of a specific subsystem or component for a given vehicle [18]. Furthermore, these suppliers can also be process specialists like metal pressers, die casters, injection moulders or forging shops [17]. The component or subsystem can be, for example, a complete seating assembly, delivered directly to the OEM [19]. 
d) The raw material supplier undertakes the role of supplying raw materials ${ }^{1}$ to both the OEMs and their suppliers [17]. Required parts and components need to reach the assembly line in time and in the required condition, otherwise production might be stopped and every 60-90 seconds the profit of one car is lost for the OEM. In addition to this, if the OEM is expecting a delay of key components and special transport might be involved, the cost will be increased further [20].

This paper, as it was mentioned earlier, concentrates on the engine producers and their place in the ASC. The above-mentioned classification is applied to a supply chain where the engine producer is in the focus (Figure 2).

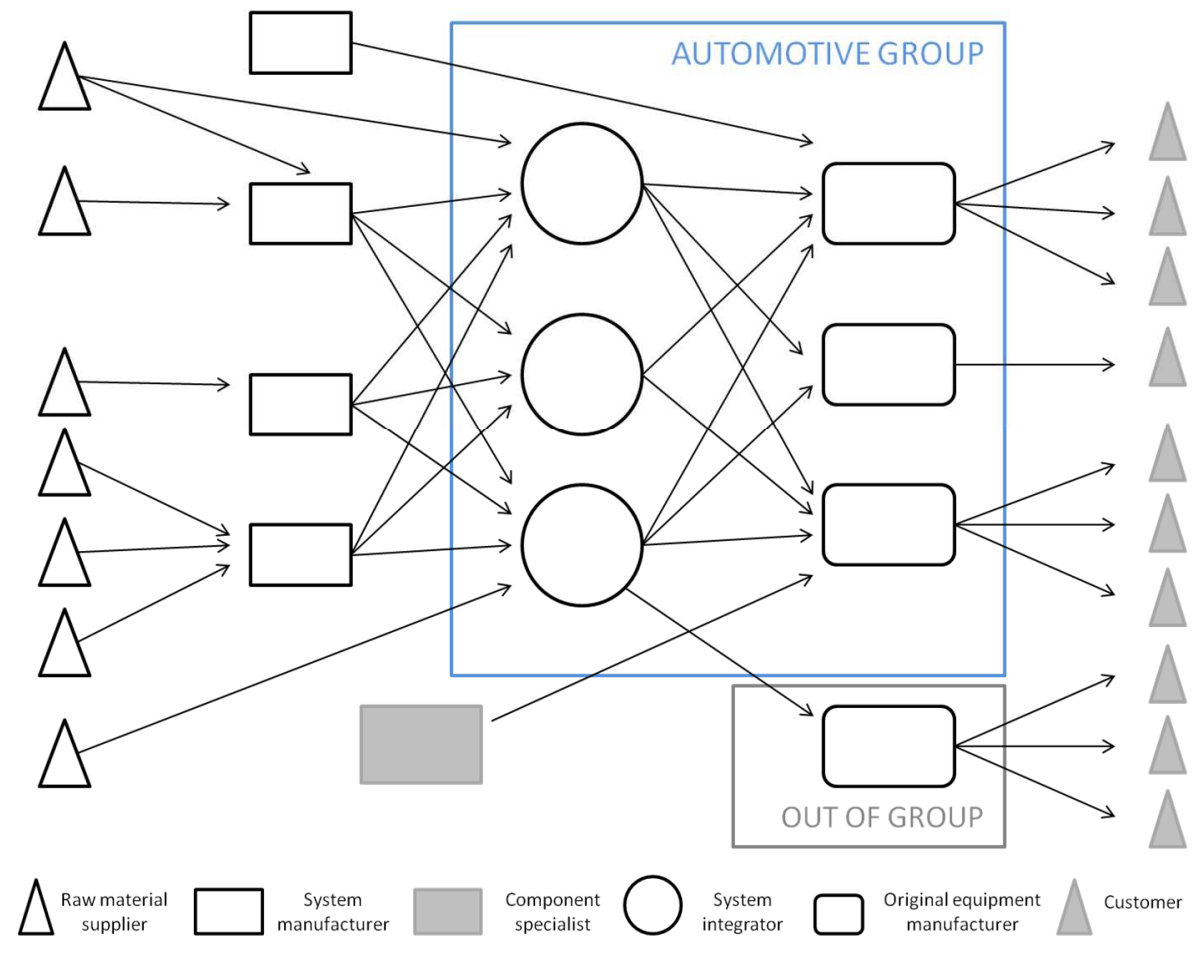

Figure 2. Automotive supply chain

This classification of the ASC can be seen in Figure 2. In this case, the engine company plays the role of system integrator, then the OEM complies with the vehicle-assembling factory. It has to be highlighted that the engine producers of the automotive industry usually belong to the same ownership group as the OEM. This way the largest part of their products is sold for the concern or group subsidiaries. Furthermore, a part of their suppliers is shared with other engine producers and the OEMs also within the group. Because of this special ownership structure, the ASC should be organised differently from any other industries, and packaging decisions will also be significantly affected.

\footnotetext{
${ }^{1}$ These materials can be steel coils, aluminum ingots and polymer pallets, etc.
} 
Naturally, the above-mentioned complicated decision-making model can be simplified, resulting in different benefits, but it can also cause indefinite limitation among participants.

\section{Forms and functions of packaging}

Packaging is a significant element in the logistics system; therefore it is listed among the key logistical activities described by Stock and Lambert (2001) [21]. Apparently, it also has a remarkable impact on the costs and performance of logistics, especially in the transport and warehousing area [22][23].

The functions of packaging can be classified as follows [24]:

(1) Product and environment protection (physical, safety, natural deterioration, waste reduction)

(2) Logistics containment and handling (unit, bulk, pallet, containers)

(3) Information (symbol, logo, description)

In the field of logistic packaging (industrial transportation, or even consumer packaging) the companies make decisions in order to determine the optimal packaging expenses, technically. This decision-making situation practically means a choice between the one-way and reusable (disposable or returnable) packaging systems[1][25]. Naturally, also in the automotive industry, the primary function of packaging is the protection of products and parts optimised by the total costs of logistics. This way, even if shipping is performed on land or sea, by rail, trucks, vessels or multi-mode shipping, the distribution environment and logistics costs together define the possible form of packaging [26][27], and then determine the final solution from disposable to returnable packaging and systems.

Managing returnable packaging systems requires more than just inverse transportation. The cleaning and maintenance of containers, as well as the storage and the administration are also involved in the process 0 . Returnable packaging has been frequently used, for example, in the US automotive industry, in order to reduce waste, costs, transport damages and to enable JIT deliveries [29]. Standardised shipment materials are usually used as returnable packaging in the ASC, like the EUR/-EPAL pallets, racks, containers and specialty bins for certain types of parts [20].

Although several forms of returnable devices can be observed in practice, their function is built up from the same conceptual structure. The complexity of the system should be higher if the number of participants on the different levels is increased, as it is illustrated in Figure 3. As it can be seen in the figure, the organisation of the returnable system, with a more complex degree, can typically only be achieved with standardised devices. But, we have to emphasise that such packaging devices exist that are not directly returned, but reused, or returned partly filled with products. ${ }^{2}$ This may also happen with disposable packaging, if it can fulfil its role again. The "pooling" system is basically a rental opportunity of packaging with standardised devices. In this case, the user takes advantage of a rental service, as the alternative of the purchasing of returnable packaging. On the

\footnotetext{
${ }^{2}$ The most typical example of this is the exchange system of EU pallets among companies in a worldwide network.
} 
one hand, with the usage of the system, the amount of fixed assets is reduced, and on the other hand, it is possible to improve the efficiency of the logistics packaging processes by eliminating the hidden expenses, which has a direct effect on the total costs of packaging [30].

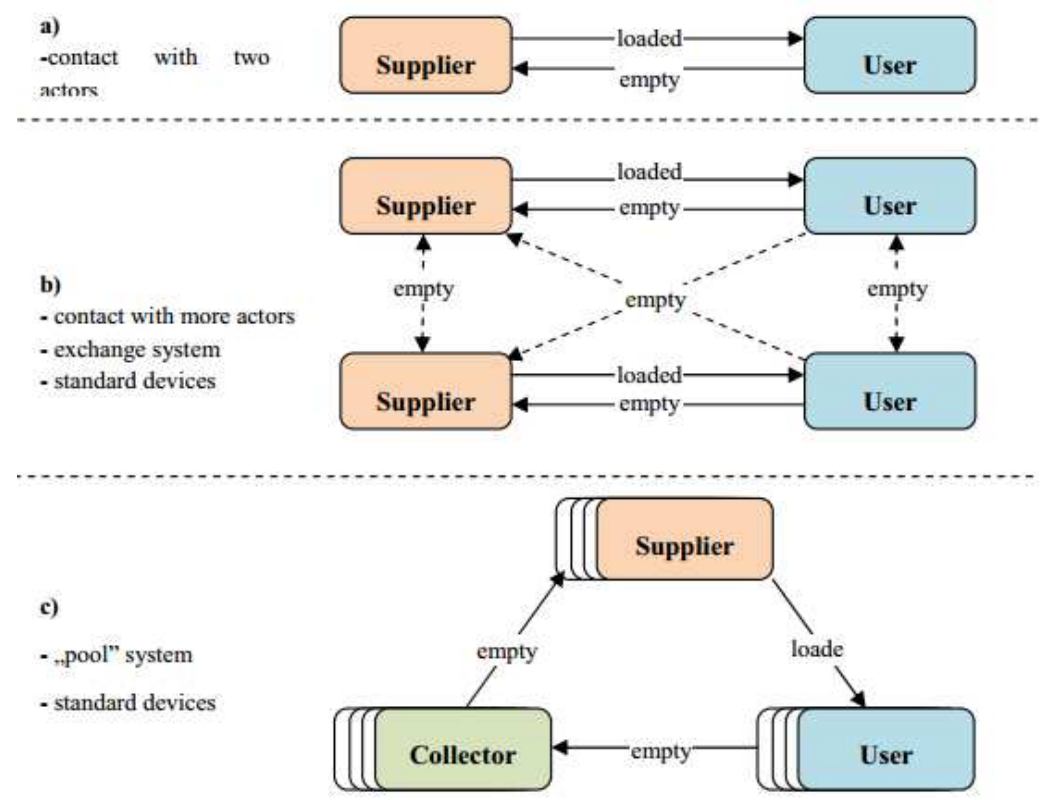

Figure 3. Organisational levels of a returnable system [30]

Although detailed analyses have to be carried out, before making the decision of choosing the right packaging system, in most cases the joint negotiation between the different participants in the chain is not proposed. Usage of the system is usually differently interpreted by the consecutive elements of the chain. Therefore one-way devices can be used as returnable and reverse, even serving different functions [25][31]

Returnable packaging management is divided into two different modes by Zhang et al. (2015):

(1) shared mode (or buyer-managed mode) which means that the assembler owns the packaging and the packaging can be shared between the suppliers; and

(2) dedicated mode (or vendor-managed mode) which means suppliers own the packages themselves and no package can be shared between suppliers. The dedicated mode has the advantage of easy management, while shared mode is better in reducing safety stock and damages of packages. [32] 
Stakeholders in a traditional PSC could be regulators, converters ${ }^{3}$ (or packaging producers), fillers ${ }^{4}$, suppliers, sellers, end customers, end-of-life managers ${ }^{5}$ and actors of the transportation channel [33].

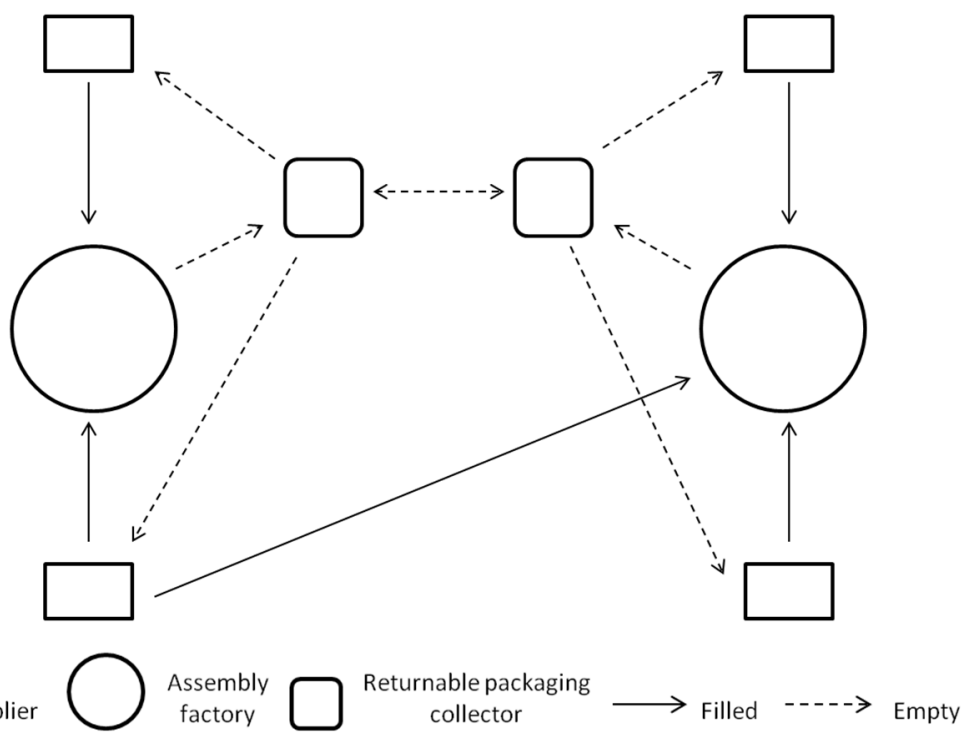

Figure 4. Industrial packaging supply chain (based on [31])

The most important actors of an industrial PSC (Figure 4) are suppliers, assembly factories and packaging collectors (if returnable packaging is used). Packaging producers are also important, but choosing the right packaging for the product belongs to the competency of the factories, their suppliers or both together.

\footnotetext{
${ }^{3}$ Convert materials to packages.

${ }^{4}$ Fill packages with products.

${ }^{5}$ Recycling, reuse and reprocessing belongs to this category.
} 


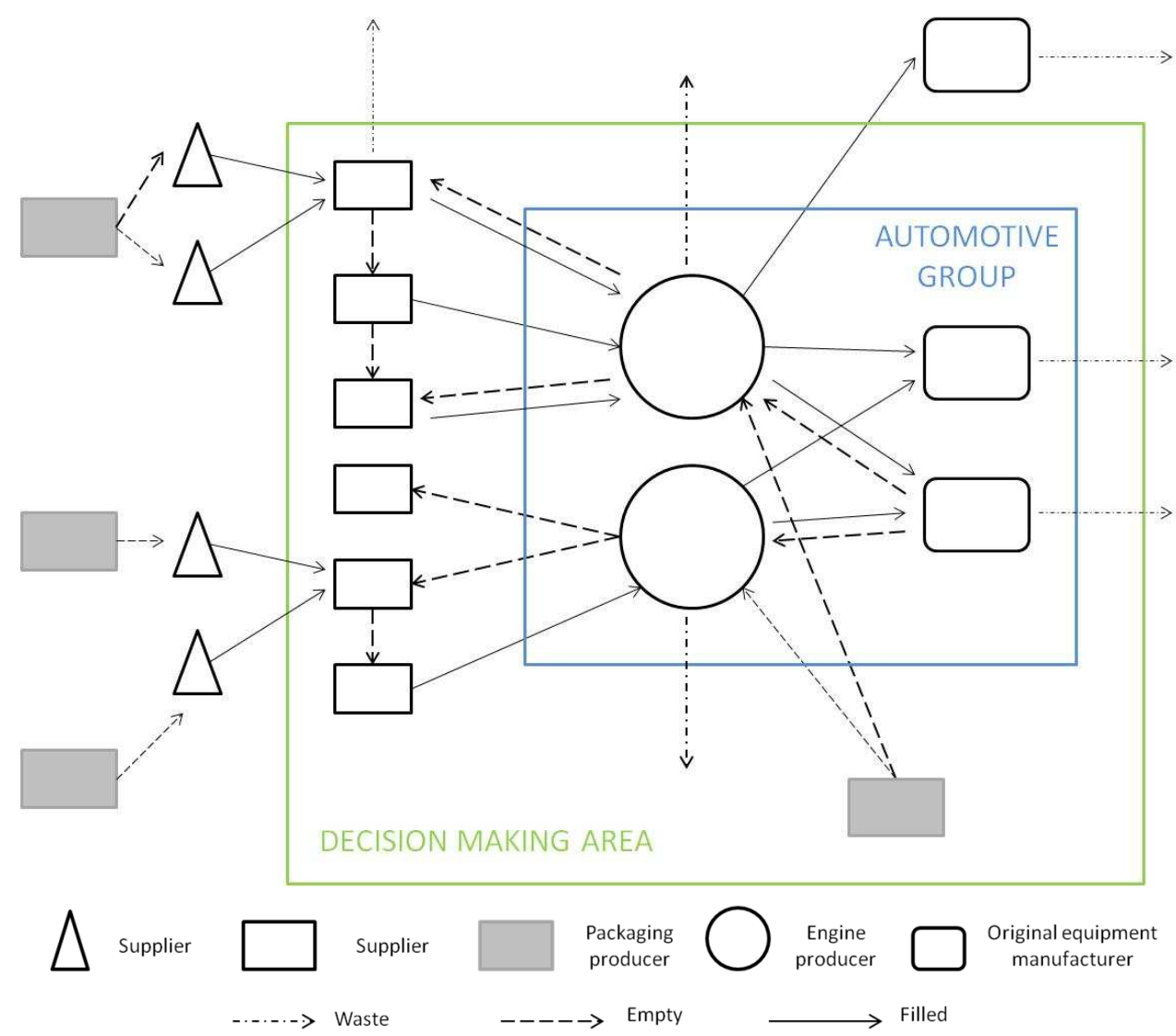

Figure 5. Packaging supply chain of an engine company

The differences between the traditional packaging supply chain (PSC) and automotive engine PSC are apparent. All of the organisational levels are present in the network, as it is represented in Figure 3, but returnable packaging is more common on the outbound flow of the engine companies. Decision-making on choosing the different types of packaging exceeds the "borders" of the automotive group companies and usually the suppliers "suffer" its consequences. Although in the aforementioned example it is apparent that the so-called shared mode (where suppliers are also involved in the process) can be more cost-reducing. In the next chapter, these types of packaging costs will be discussed.

\section{The costs of automotive packaging}

It has been found that paying limited attention to packaging can cause higher costs in physical distribution. Furthermore, researchers argue that packaging should not only be considered from a cost point of view, but its role as a value-added function in the SC is also important [33]. 
The three phases of the decision-making mechanism can be determined as follows [25]:

- $\quad$ identifying the rising packaging costs;

- determining the direct packaging costs;

- allocating packaging costs.

Unfortunately, according to corporate experience, adequate information to measure the real costs of packaging is very rarely available. However, if formation of the suitable packaging tools and the system is handled at the right phase of the product planning process, the development of a feedback mechanism is possible. Only taking the material costs into account leads to a wrong or non-optimal result, and it would be very important to consider, for example, recycling, too. The types of the costs are listed in Table 1.

Table 1. The relation between disposable and returnable packaging costs among the engine packaging supply chain actors

\begin{tabular}{|c|c|c|c|}
\hline \multicolumn{2}{|r|}{ Type of cost } & \multirow{2}{*}{$\begin{array}{c}\begin{array}{c}\text { Engine } \\
\text { PSC }\end{array} \\
\mathrm{a}, \mathrm{b}\end{array}$} & \multirow{2}{*}{$\begin{array}{c}\text { Relation } \\
\mathrm{D}>\mathrm{R} \\
\end{array}$} \\
\hline Material cost & Packaging material cost & & \\
\hline & Cost of packaging accessories & $\mathrm{a}, \mathrm{b}$ & $\mathrm{D}>\mathrm{R}$ \\
\hline \multirow{4}{*}{$\begin{array}{l}\text { Equipment cost } \\
(\text { EUR/kWh, } \\
\text { EUR/GJ) }\end{array}$} & Depreciation & $\mathrm{b}$ & $\mathrm{D} \sim \mathrm{R}$ \\
\hline & Capital asset & $\mathrm{b}$ & $\mathrm{D}<\mathrm{R}$ \\
\hline & Operating cost & $\mathrm{d}$ & $\mathrm{D}<\mathrm{R}$ \\
\hline & Energy cost & $\mathrm{a}$ & $\mathrm{D}>\mathrm{R}$ \\
\hline \multirow{4}{*}{$\begin{array}{c}\text { Transportation cost } \\
\text { (EUR/km, } \\
\text { EUR/freight) }\end{array}$} & Material loss & $\mathrm{a}, \mathrm{b}$ & $\mathrm{D} \sim \mathrm{R}$ \\
\hline & Capital asset & $\mathrm{a}, \mathrm{b}$ & $\mathrm{D} \sim \mathrm{R}$ \\
\hline & Labour cost & $\mathrm{a}, \mathrm{b}$ & $\mathrm{D} \sim \mathrm{R}$ \\
\hline & Energy cost & $\mathrm{a}, \mathrm{b}$ & $\mathrm{D} \sim \mathrm{R}$ \\
\hline \multirow{5}{*}{$\begin{array}{c}\text { Storage cost } \\
(\text { EUR/m²/day, } \\
\text { EUR/pallet/day) }\end{array}$} & Material loss & $\mathrm{d}$ & $\mathrm{D} \sim \mathrm{R}$ \\
\hline & Capital asset & $\mathrm{d}$ & $\mathrm{R}$ \\
\hline & Storage hiring cost/Real estate cost & $\mathrm{d}$ & $\mathrm{D}>\mathrm{R}$ \\
\hline & Operation cost & $\mathrm{d}$ & $\mathrm{D} \sim \mathrm{R}$ \\
\hline & Energy cost & $\mathrm{d}$ & $\mathrm{D}>\mathrm{R}$ \\
\hline $\begin{array}{l}\text { Handling cost } \\
\text { (EUR/hour) }\end{array}$ & Labour in packaging process & $\mathrm{d}$ & $\mathrm{D} \sim \mathrm{R}$ \\
\hline \multirow{4}{*}{$\begin{array}{l}\text { Derivable cost } \\
\quad(\mathrm{EUR} / \mathrm{pc})\end{array}$} & Reparation cost & $\mathrm{b}$ & $\mathrm{R}$ \\
\hline & Inventory shortage & $\mathrm{c}$ & $\mathrm{D}>\mathrm{R}$ \\
\hline & Cost of returned product & $\mathrm{b}$ & $\mathrm{D} \sim \mathrm{R}$ \\
\hline & Collection and sorting cost & $\mathrm{b}, \mathrm{c}$ & $\mathrm{D}<\mathrm{R}$ \\
\hline
\end{tabular}




\begin{tabular}{|c|l|c|c|} 
& Recycling cost & $\mathrm{b}, \mathrm{c}$ & $\mathrm{D}>\mathrm{R}$ \\
\cline { 2 - 4 } & Destruction cost & $\mathrm{b}, \mathrm{c}$ & $\mathrm{D}>\mathrm{R}$ \\
\hline \hline \multirow{4}{*}{$\begin{array}{c}\text { Other costs } \\
(\text { EUR/kg) }\end{array}$} & Deposit fee & $\mathrm{a}$ & $\mathrm{R}$ \\
\cline { 2 - 4 } & Cleaning and reparation cost & $\mathrm{b}$ & $\mathrm{R}$ \\
\cline { 2 - 4 } & Management and administration cost & $\mathrm{d}$ & $\mathrm{D}<\mathrm{R}$ \\
\cline { 2 - 4 } & Insurance & $\mathrm{a}, \mathrm{b}$ & $\mathrm{D} \sim \mathrm{R}$ \\
\cline { 2 - 4 } & Cost of damages & $\mathrm{a}$ & $\mathrm{D} \sim \mathrm{R}$ \\
\hline
\end{tabular}

$\mathrm{a}=$ supplier

$\mathrm{b}=$ engine company

$\mathrm{c}=\mathrm{OEM}$

$\mathrm{d}=$ shared

$\mathrm{D}=$ disposable

$\mathrm{R}=$ returnable

There are costs interpretable for returnable packaging only, like capital asset cost for storage or cleaning and reparation. Some costs are almost the same in case of both disposable and returnable packaging, the difference is negligible. Overall, it can be stated considering the system as a whole, that the relative cost of returnable packaging is lower. Of course, it depends on who the cost-bearer is. In Table 1, these costs are divided among the ASC actors. In many cases costs are shared (for example storage and handling costs, administration cost, etc.), but the OEM devolves many costs to the suppliers and the engine company. Introducing packaging guidelines - independent from the type of the system - can result in cost reduction by reducing the used material and recycling.

\section{Conclusion}

Returnable packaging is dominant in the automotive packaging supply chain. Both disposable and returnable packaging is used, but returnable is preferred especially in the deliveries between the engine producer and the OEM. By choosing the suitable packaging tools and systems, the decision-making area is wider than the automotive group ownership "border" in the aspect of packaging supply chain. This behaviour thereby means a further stabilisation for the group's own processes.

\section{References}

[1] Böröcz P, Földesi P: The application of the game theory onto the analysis of the decision theory of logistic packagings, Acta Technica Jaurinensis, Vol 1, No. 2, pp. 259-268, 2008.

[2] Yam K L: The Wiley encyclopedia of packaging technology. Wiley, USA, 2009.

[3] Mojzes Á, Böröcz P: Decision Support Model to Select Cushioning Material for Dynamics Hazards During Transportation Acta Technica Jaurinensis, Vol 8, No. 2, pp. 188-200, 2015. 
[4] Smith A D: Green Supply Chain Management and consumer sensitivity to greener and leaner options in the automotive industry. International Journal of Logistics Systems and Management, Vol. 12, No. 1, pp. 1-31., 2012.

DOI: 10.1504/IJLSM.2012.047056

[5] Gnoni M G, Felice F, Petrillo A: A Multi-Criteria Approach for Strategic Evaluation of Environmental Sustainability in a Supply Chain. International Journal of Business In-sights \& Transformation, Vol. 3, No. 3, pp. 54-61., 2011.

[6] European Commission: Packaging and Packaging Waste, 2015. http://ec.europa.eu/environment/waste/packaging/index en.htm (access on 26. 05. 2016)

[7] Hellström D, Johansson O: The impact of control strategies on the management of returnable transport items, Transportation Research Part E. Logistics and Transportation Review, Vol. 46, No. 6, pp. 1128-1139., 2010.

DOI: $10.1016 /$ j.tre.2010.05.006

[8] Böröcz P, Filep B: A fuzzy approach for Finding an Ideal Location of Industrial Park Area, Acta Technica Jaurinensis, Vol. 2, No. 3, pp. 493-511., 2009

[9] Lowry W: A must-know investor's guide to Ford Motor Company, 2014. http://marketrealist.com/2014/05/must-know-investors-guide-ford-motorcompany/ (access on 11. 04. 2016)

[10] Volkswagen production plants, 2015. http://www.volkswagenag.com/content/vwcorp/content/en/the_group/productio n_plants.html (access on 05. 04. 2016)

[11] Battini D, Boysen N, Emde S: Just-In-Time supermarkets for part supply chain in the automotive industry. Journal of Management Control, Vol. 24, No. 2, pp. 209-217., 2013.

DOI: $10.1007 / \mathrm{s} 00187-012-0154-\mathrm{y}$

[12] Kalmbach R, Bernhard W, Kleimann P G, Hoffmann M: Automotive landscape 2025 - Opportunities and challenges ahead, 2011. https://www.rolandberger.com/media/pdf/Roland_Berger_Automotive_Landsc ape_2025_20110228.pdf (access on 11.05.2016)

[13] Funda P: Globales Wachstum- Chance oder Risiko? Analyse und Prognose der Automobilproduktion in Deutschland, Europa und weltweit, 2014. http://www.pwc.de/de/automobilindustrie/das-wachstum-der-weltweitenmaerkte-bringt-grosse-chancen-aber-auch-herausforderungen-fuer-diedeutsche-automobilindustrie.html (access on 11. 05. 2016)

[14] Kerkow U, Martens J, Müller A: Vom Erz zum Auto - Abbaubedingungen und Lieferketten im Rohstoffsektor und die Verantwortung der deutschen Automobilindustrie, 2012. https://germanwatch.org/de/download/8864.pdf (access on 11. 05. 2016) 
[15] Doran D: Supplying on a modular basis: an examination of strategic issues. International Journal of Physical Distribution \& Logistics Management, Vol. 35, No. 9, pp. 654-663, 2005.

DOI: $10.1108 / 09600030510632023$

[16] Pereira G M, Sellitto M A, Borchardt M, Geiger A: Procurement cost reduction for customized non-critical items in an automotive supply chain: An action research project. Industrial Marketing Management, Vol. 40, No. 1, pp. 28-35, 2011.

DOI: 10.1016/j.indmarman.2010.09.007

[17] Veloso F, Henry C, Roth R, Clark J: Global Strategies for the Development of the Portuguese Autoparts Industry, 2000. http://in3.dem.ist.utl.pt/labpolicy/docs/part_b5_4.pdf (access on 12. 15. 2016)

[18] Veloso F, Kumar R: The Automotive Supply Chain: Global Trends and Asian Perspective, 2002. http://repository.cmu.edu/cgi/viewcontent.cgi?article=1131\&context=epp (access 12.05. 2016)

[19] Doran D: Rethinking the supply chain: an automotive perspective. Supply Chain Management: An International Journal, Vol. 9, No. 1, pp. 102-109, 2004.

DOI: $10.1108 / 13598540410517610$

[20] Boysen N, Emde S, Hoeck M, Kauderer M: Part logistics in the automotive industry: Decision problems, literature review and research agenda. European Journal of Operational Research, Vol. 242, No. 1, pp. 107-120, 2015. DOI: 10.1016/j.ejor.2014.09.065

[21] Stock J R, Lambert D M: Strategic Logistics Management, New York: McGraw-Hill Higher Education, 2001.

[22] Twede D: The process of logistical packaging innovation. Journal of Business Logistics, Vol. 13, No. 1, pp. 69-94, 1992.

[23] Bowersox D J, Closs D J, Cooper M B: Supply Chain Logistics Management, New York, McGraw - Hill / Irwin, 2002.

[24] Böröcz P, Mojzes Á: The importance of packaging in logistics (in Hungarian: A csomagolás jelentősége a logisztikában), Transpack, Vol. 8, No. 2, pp. 2832, 2008.

[25] Böröcz P.: Analysing the functions and expenses of logistics packaging systems, Proceedings of FIKUSZ '09 Symposium for Young Researchers, pp. 29-39, 2009

[26] Böröcz P, Vastag Gy: Good Vibrations: Lessons from Packaging for the Global Supply Chain, POMS 26th Annual Conference, Washington, USA, Production and Operations Management Society, pp. 1318, 2015.

[27] Böröcz, P, Singh SP. Measurement and Analysis of Vibration Levels in Rail Transport in Central Europe. Packaging Technology and Science, 2016 
DOI: $10.1002 /$ pts.2225.

[28] Kroon L, Vrijens G: Returnable containers: An example of reverse logistics. International Journal of Physical Distribution and Logistics Management, Vol. 25, No. 2, pp. 56, 1995.

DOI: $10.1108 / 09600039510083934$

[29] Witt C E: Are reusable containers worth the cost? Material Handling Management, Vol. 55, No. 7, pp. 75, 2000.

[30] Dubiel M: Costing Structure of Reusable Packaging Systems, Packaging Technology and Science, Vol. 9, No. 5, pp. 237-254, 1996.

DOI: 10.1002/(SICI)1099-1522(199609)9:5<237::AID-PTS368>3.0.CO;2-7

[31] Böröcz P, Singh SP, Singh J: Evaluation of Distribution Environment in LTL Shipment between Central Europe and South Africa, Journal of Applied Packaging Research, Vol. 7, No. 2, Article 3, 2015.

DOI: $10.14448 /$ japr.04.0003

[32] Zhang Q, Segerstedt A, Tsao Y C, Liu B: Returnable packaging management in automotive parts logistics: Dedicated mode and shared mode, International Journal of Production Economics, Vol. 168, pp. 234-244, 2015.

DOI: 10.1016/j.ijpe.2015.07.002

[33] Chan F T S, Chan H K, Choy K L: A systematic approach to manufacturing packaging logistics. International Journal of Advanced Manufacturing Technology, Vol. 29, No. 9-10, pp. 1088-1101, 2005.

DOI: $10.1007 / \mathrm{s} 00170-005-2609-\mathrm{x}$

[34] Reusable Packaging Association: What is Reusable Packaging? , 2015. http://reusables.org/choose-reusables/what-is-reusable-packaging (access on 21. 05. 2016) 